\title{
(Re)viewing the Warrior Woman: Reading the Old English "Iceberg" Riddle from an Ecofeminist Perspective
}

\author{
Corinne Dale ${ }^{1}$
}

Published online: 12 March 2019

(c) The Author(s) 2019

\begin{abstract}
The Exeter Book's Riddle 33 depicts its subject, an iceberg, as a warrior woman who can cause damage to ships with her physical prowess and powerful curses. This article discusses the riddle's union of woman and iceberg from an ecofeminist perspective, exploring the deep-rooted andro- and anthropocentric anxieties that lie behind it. It explores the riddle alongside some of its analogues, including Beowulf, the metrical charms and the Icelandic "wave" riddles, which contain destructive female figures who are associated with dangerous and destructive elements of nature, including water and disease. As well as exploring some of the riddle's connections with these analogues and their underlying anxieties, it also brings the riddle into dialogue with modern ecofeminists. In doing so, this article also considers how the union of the iceberg and warrior woman might offer an empowering metaphor beyond the stereotypical association of the female with fertile land.
\end{abstract}

Keywords Old English · Exeter Book · Riddle 33 - Iceberg · Warrior woman · Ecofeminism

Riddle 33, from the Old English Exeter Book, depicts its solution "iceberg" as an "eternally conceiving" (Williamson 1977: p. 242) warrior woman who wrecks ships with her martial prowess and utters curses with her booming voice. Her ability to destroy with words and actions, as well as spontaneously reproduce more of her destructive race, means she poses a triple threat to those humans who come into contact with her. Because the iceberg is a female warrior, the riddle invites us to contemplate the ways in which this dangerous force reflects early medieval views of women and their ability to cause destruction. A variety of analogues, including Beowulf, the metrical charms and the Icelandic "wave" riddles, with their depictions

\footnotetext{
1 I use Krapp and Dobbie's numbering system for the riddles.

Corinne Dale

corinne_dale@yahoo.co.uk

1 Parliament Hill School, Highgate Road, London NW5 1RL, UK
} 
of destructive female figures in various guises, suggest that Riddle 33's warrior woman came from deep-rooted anthropocentric and androcentric anxieties about the mysterious and fearsome qualities of women and the natural world. Beyond the stereotypical view of women-as-earth, waiting to be "plowed and fulfilled" (Cowan 2017: p. 6), these female figures are not associated with fertile land, but with the more dangerous and destructive elements of nature, including water and disease. This study aims to illuminate the andro- and anthropocentric attitudes behind Riddle 33 by forging connections with these analogues; but it also brings the riddle into dialogue with modern ecofeminists seeking a "new reality" for women beyond the essentialist view of women-as-land (Cowan 2017: p. 6). An iceberg is a part of nature that cannot easily be controlled or used by humans and, when feminised, as it is in Riddle 33, can offer an empowering metaphor for women and nature.

The title of this study states that this is an ecofeminist reading of Riddle 33 and, at its heart, it is. I explore the relationship between women and nature in the text and the aforementioned analogues and examine them as products of patriarchal societies. Ecofeminism, originally a movement that sought to "address gender-based issues and to conserve and preserve human and non-human habitats" (Murphy 2018: p. $1)^{2}$ has been applied to literary texts since the 1990 s, and is enjoying renewed interest today. However, the very foundation of ecofeminism is problematic for feminists seeking to shake off the binary associations of women/nature and men/culture. For some, these associations are an "instrument of oppression, a relic of patriarchy that should simply be allowed to wither away" (Plumwood 2002: p. 2). Yet, as new attitudes towards female bodies emerge, women can start to think anew about the metaphorical potential of nature to describe their own realities (Cowan 2017: pp. 6-8). And, as we become more aware of the catastrophic damage human beings have done to the environment, so the need to explore representations of nature beyond not only the anthropocentric but also the androcentric viewpoint has also emerged. If we are to see humans as part of, not separate from, nature, then it follows that we must also see ourselves as nature, whether male or female. A text allows for the union of human and nature in imaginative metaphors and fantastical scenarios where women can be water-creatures and trees can be thanes. ${ }^{3}$ It is a fruitful medium for ecological thought.

Ecofeminism has only very recently been brought into Anglo-Saxon studies, but it has already proven to be a useful tool, bringing to light aspects of these thousand-year-old texts that might otherwise be overlooked. An ecofeminist reading of Beowulf by Heide Estes, for example, "rewards concentration on Grendel's mother as well as the space in which she lives" (2015: p. 209). In so doing, the reading shows that the poem both "confronts" and "complicates" the tendency to see humans as separate from nature (Estes 2015: p. 209). Ecofeminism also invites interdisciplinary approaches to literary texts that make connections between past and present attitudes to women and nature. In a recent article, Lees and Overing (2017) set out

\footnotetext{
2 See Murphy's introduction for an overview of the history of ecofeminism. For the history of ecofeminism in literary criticism see also Murphy and Gaard (2000: p. 1).

3 I refer here to Grendel's Mother and Exeter Book Riddles 53 and 73.
} 
a bold vision for a multidisciplinary approach to women and water in the humanities that connects the two subjects across time, discussing Anglo-Saxon concepts of the monstrous alongside the work of contemporary American artist Roni Horn. In the process, they contemplate their own identities-are they "literary scholars, historians, medievalists or feminists"? - and demonstrate that it is possible, perhaps necessary, to speak with more than one critical voice (Lees and Overing 2017: p. 97). This present study is itself a hybrid of approaches that speaks across time: it explores the gender issues lurking behind Riddle 33 (which reveal at best anxieties about powerful females, at worst only an incidental marriage of ice and woman) and contemplates how, despite these issues the iceberg-woman metaphor might still have something to offer modern ecofeminist philosophy.

\section{I}

Past readings of Riddle 33 would suggest that there is nothing significant about the gender of its subject. Besides two mentions by Lees and Overing (2017: p. 107, 2001: p. 104), the little scholarship we have on Riddle 33 makes no comment on the significance of the use of hio in line 5 or the rare glimpse we get of a fighting female. It comes as no surprise that Stopford A. Brooke referred to Riddle 33's subject using masculine pronouns in his (1892) study (p. 181), but other, far more recent, studies have also side-lined the poet's use of hio. In Anita R. Reidinger's (2004) discussion of the depiction of the iceberg as a warrior, there is no mention of gender and her translation offers a gender-neutral subject (pp. 30-43). Indeed, the gender of riddle subjects has rarely been the focus of Old English riddle analysis, with most studies interested in identifying new solutions and analogues, or understanding how the riddle genre as a whole functions. ${ }^{4}$ One of the few studies we have is John D. Niles' (2006) analysis of the riddles' solutions. Niles' study suggests that, for many of the riddles, the depiction of a subject's gender was driven by the grammatical gender of the solution-that is, not the concept of the solution, but the Old English word for that solution. Niles gives the example of Riddle 16, which has the answer "anchor": "The exact answer is not the concept "anchor," however, as is sometimes carelessly stated or assumed; rather it is the OE word ancor, which is grammatically masculine, for the riddle is phrased in such a manner that only a masculine noun will provide the solution" (2006: p. 105). According to Niles, the gendered depiction of a subject can help guide the reader to the answer. If correct, this theory would suggest that the decision to marry water and ice in Riddle 33 might have stemmed from nothing more than a desire to adhere to the rules of grammar. However, as this present study aims to show, there is much more behind the gendering of the riddle's icy subject than grammatical associations. To explain away the subject's gender on this

\footnotetext{
${ }^{4}$ See, for example, Murphy (2011) and Bitterli (2009).
} 
account would be akin to explaining away the gender of the Anglo-Saxon elegies' female subjects on account of a scribal error, as some critics have done in the past. ${ }^{5}$

Riddle 33, like a large number of other Old English riddles, presents its subject through the lens of heroic culture. Where, for example, Riddle 5 depicts a shield as a wounded thane and Riddle 73 imagines a spear as a comrade in arms, Riddle 33 offers us the image of a fierce warrior who carves into shields with its sharp edges. Here is the riddle in full:

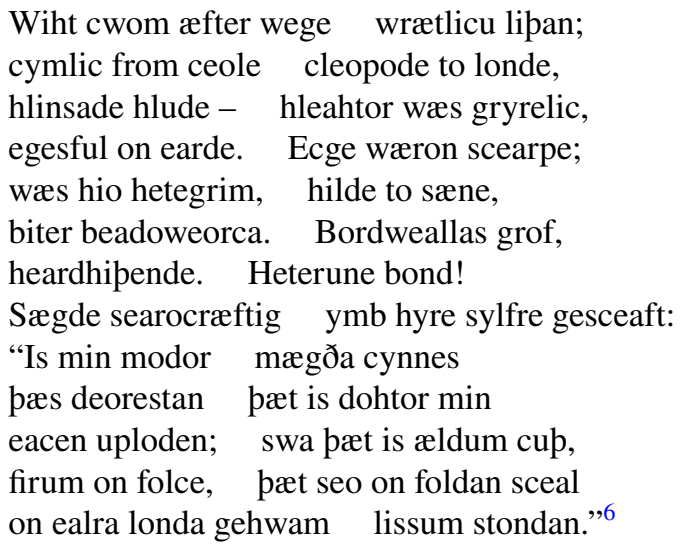

(A rare, beautiful creature came sailing along the wave, called from its throat to the land, resounding loudly; the laughter was fearsome, terrible on earth; her edges were sharp. She was cruel, slow to combat, her battle-work was fierce; [she] carved into the ship-walls, plundering hard. She bound a hateful curse; the crafty one spoke about her own creation: "My mother is from the dearest of women-kind; that is my daughter, [who] grew up pregnant-so it is evident to men, to people in a nation, that she must stand blessedly on earth, in each and every land.”)

However, this is not the heroic male figure who has performed brave deeds in battle, serving alongside a lord or else seeking a physician for its wounds. Instead, it is a fierce female figure who destroys ships with her physical and verbal power and creates her own riddle about her mysterious ancestry. Even though the writer depicts a warrior-like subject, the riddle is perhaps most closely aligned with Riddle 84 (11. 9a-10a), whose subject, water, is depicted as a monstrous, rampaging force of nature with a similarly mysterious ancestry, as opposed to a weapon-bearing thane. Both these riddles' subjects are not natural entities that can be bound, shaped and

\footnotetext{
5 As Shari Horner notes, "most of the criticism supporting a male speaker appeared in the early to mid 1960 s, and was effectively refuted by Angela Lucas" (2001: p. 55). See also Lucas (1969).

6 All citations from the Old English riddles are from Williamson (1977), since I follow Williamson's emendations of certain Old English words in my translation. All translations from Old English to modern English, including those texts outside of the riddle collection, are my own.
} 
ultimately controlled by humans, like the trees of Riddle 53 and 73, for example, ${ }^{7}$ but are forces of nature that defy human mastery and cannot be easily explained. They are both female, too, and allude to their ability to reproduce more of their kind (Riddle 84, 11. 4 and 21).

The first four lines of Riddle 33 describe an attractive but intimidating creature. This creature is said to be cymlic (lovely or beautiful) (1. 2a), yet she has a laugh that is gryrelic (fearsome or horrible) (1. 3b). The creature is also vocal and the sound contributes to her intimidating nature. Her voice, which apparently originates from her ceole (throat) (although ceole has also been interpreted as "ship," "chill" or "cold" 8 ), is described as hlinsade hlude (resounding loudly) (1l. 2a-3a). That the iceberg might make a noise is a little surprising, but we might imagine these to be the sound it makes when it breaks up or when it collides with a ship. After the initial description of her appearance and voice, we are presented with a creature performing beadoweorca (battle-work) and destroying ships with her sharp edges (there is a clever play on the word bordweallas here). ${ }^{9}$ Next, we are told that the creature bond (bound) a heterune (hateful curse) and can speak about her own gesceaft (creation) (11. 7b-8b)_perhaps the most perplexing part of the iceberg metaphor. Finally, we learn about the creature's peculiar female ancestry: her mother is also her daughter. Here, the riddle-writer captures the process of freezing and melting, with both water and ice depicted as "eternally conceiving" (Williamson 1977: p. 242).

The first half of the riddle is essentially a complex metaphor in which the destructive power of an iceberg is equated with the destructive power of a warrior equipped with weapons and curses. The second half of the riddle takes a different approach to its subject by offering a riddle-within-a-riddle that tests the reader with its icewater paradox. The second half appears to be influenced by a long-standing tradition of ice-water/mother-daughter analogies. "In traditional riddling," says Patrick J. Murphy, "ice is the daughter of water and the mother of water as well. The idea is a standard conceit, well known both in English oral tradition and as a default example of aenigma in many medieval texts" (2011: p. 10; see also Tupper 1910: p. 147). Riddle 33 clearly makes use of this conceit in its final lines, offering a gendered depiction of water and ice as mother and daughter. The final thirteen-line product appears to be a hybrid, a splicing together of two traditions, Latin and Old English, which is certainly not unusual in the Exeter Book riddle collection (see Bitterli 2009).

If the riddle-writer was working with a received concept of water and ice as mother and daughter, this may arguably have led to the depiction of the iceberg as female in lines 1-7, the new or "original material of this riddle" (Beechy 2010: p. 95). This suggestion, however, would be erroneous. Feminine pronouns are not used in the description of the warrior simply because the mother-daughter paradox demands it, but because of a more deep-rooted association of women and water and

\footnotetext{
7 See Dale (2017: pp. 103-122), for a discussion of these trees as controlled and shaped by humans.

8 For "ship" see Murphy (2011: p. 9); for "chill” or "cold," as well as "ship," see Beechy (2010: p. 61). I follow Williamson, who puts forward a compelling argument for emending ceole to ceolan (1977: pp. 239-240).

9 Williamson notes that bordweallas is probably a pun on shield-walls (1977: p. 240).
} 
all their destructive potential and mystery. As previously mentioned, the warrior in the first half of the riddle is not like those masculine warriors of other Exeter Book riddles, like the spear/thane of Riddle 73, who fights beside his lord in an epelfasten (fortress) in a place that aer frið hafde "previously had peace" (25b-26b). She is a fully feminised warrior, a woman who fights alone in her watery domain, serving no lord, who uses her voice as much as her martial ability to inspire fear.

Women warriors are rare in Old English poetry; "women might invoke battles, as does Judith," says Dana Oswald, "but they do not fight them" (2010: p. 81). Our primary example is Grendel's Mother, the merewif mihtig (mighty sea-woman) of Beowulf, who, though undoubtedly "a woman to be reckoned with" (Oswald 2010: p. 81), still inspires less gryre (terror) than her monstrous son Grendel:

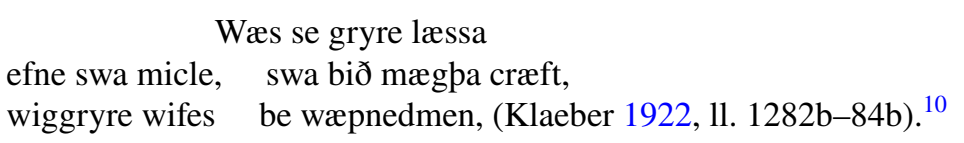

(The terror was the lesser, just as great as is a maid's art, a woman's war-terror, compared with men.)

Renée Trilling's (2007) discussion of Grendel's Mother suggests that, for AngloSaxon writers, the idea of a physically active woman was inconceivable. Trilling asserts that "an active body in [the Anglo-Saxon] cultural economy is, by definition, a masculine one" (2007: p. 15). She observes that, even though Grendel's Mother would seem to go against this notion, feminine pronouns are not always applied to the apparently female monster: "Neither the narrator nor the characters can comfortably attach a feminine pronoun to the perpetrator of an attack on Heorot," she says, and, as a result, the attacker has "on the literal level, become male" (Trilling 2007: p. 15). This issue does not seem to concern the writer of Riddle 33, who attaches two feminine pronouns to the text's female warrior. The riddle's warrior woman is, after all, an iceberg, so the writer is dealing with a figurative rather than literal fighting female.

Pronouns aside, there are a number of similarities between Riddle 33's warrior woman and Grendel's Mother. Firstly, both creatures inhabit a watery domain. Grendel's Mother lives in wateregesan...ceale streamas (terrible waters, cold streams) (11. 1260a-61a), whilst the iceberg/warrior woman sails (lipan) along the wege (wave) (1. 1). ${ }^{11}$ Men who enter their domain do not come out unscathed. Beowulf's encounter with Grendel's Mother almost kills him, whilst the men behind the bordweallas of their ship are likely to face a tragic demise. Secondly, like Grendel's mother, who inspires gryre (fear) (even if it is less than that of her son), the iceberg/warrior woman terrifies with her gryrelic (fearsome) laughter (Riddle 33, 1. 3b). A further similarity can be drawn between their reproductive capabilities. The

\footnotetext{
${ }^{10}$ Further references to Beowulf are from this edition.

11 Wege could be translated as "way" and it is possible that the ambiguity here is intentionally invoked to create further mystery.
} 
riddle-writer tells us that the subject is also her daughter eacen up liden (grown up pregnant), ${ }^{12}$ and this implies that the female subject, fertile since birth, does not need to procreate with a male. She is, as Williamson says, "eternally conceiving" (1977: p. 242). On the one hand, lines $9 a-13$ b seem like mere derivative metaphorical play; yet, when we take into consideration the identity of the subject as a warrior too, and compare her to Grendel's Mother, the final lines seem intended to generate further anxiety about the threat of this creature. "The greatest threat provided by Grendel's Mother," says Oswald, "is her identity as mother; it is through her offspring, but more centrally through her autonomous fertility that she threatens the patriarchal order" (2010: p. 83). ${ }^{13}$ Oswald says that Grendel's Mother "invokes a different kind of fear" to Grendel and argues that it is because she is a "singular origin" that she must be defeated (2010: p. 83). The creature of Riddle 33 is also a "singular origin"-both water and ice come from the same source-and, like Grendel's Mother, can also produce a "husband-less maternal creation" (Potkay and Evitt 1997: p. 45).

A particular aspect of the iceberg/warrior woman's appearance is her beauty, and this sets her apart from Grendel's Mother who has no alluring qualities. In this respect, she could be compared to Beowulf's Modthryth, a powerful, cenlicu (beautiful) (1. 1941b) female figure who brings terror to her people. Modthryth does not inhabit a watery lair, but she does perform firen ondrysne (fearsome violence) (l. 1932b). We are told that no man dared hire an dages eagum starede (stare her in the eyes at any point in the day) for fear that he would end up in walbende (deadly bonds) (11. 1935a-36a). Riddle 33's powerful female also lays bonds on men, although these are achieved through her words rather than her hands. Significantly, Modthryth is eventually married to Offa, and this union puts an end to her violent ways. We are told that she leodbealewa laes gefremede, inwitniða (performed fewer crimes, wicked deeds, against [her] people) (1l. 1946a-47b). Overing argues that Modthryth's initial behaviour "invert[s] the values of the prevailing symbolic order," but that, after marrying Offa, the threat is contained and "things are once more under the control of the masculine economy" (2000: p. 249). In Beowulf, violent women are defeated, whether by the influence of a good husband or by the sword of a warrior, as the fates of Modthryth and Grendel's Mother show respectively. As an elemental force, however, the iceberg/warrior woman of Riddle 33 cannot be defeated and remains a threat among the waves.

The attractive yet dangerous quality of Riddle 33's subject, combined with its powerful, untameable nature, invites a comparison with the Icelandic "wave" riddles and their depictions of Valkyrie-like creatures who can do damage to ships. The Valkyrie figure was well-known to Anglo-Saxon writers and may have influenced the depiction of the Grendel's Mother and Modthryth (see Damico 1990: pp. 179-181), so addressing the women of the Icelandic riddles here too makes sense. The "wave" riddles are found in Hervarar saga, a thirteenth-century text set during the war between the Goths and the Huns. The riddles form part of a contest between Odin and Heiðrek and contain Valkyrie-like maidens who echo the saga's

\footnotetext{
${ }^{12}$ I follow Williamson's translation of this phrase here (1977: p. 242).

${ }^{13}$ For more work on the theme of maternal women and patriarchal anxiety see Morgan (2006), and Acker (2006).
} 
other martial women, including Hervör. The following is just one example of a wave riddle:

Hverjar eru pær snótir

Er ganga (margar) syrgjandi

At forvitni foður?

Mörgum mönnum

Hafa pær at meini orðit;

Við pat munu pær sinn aldr ala. (Burrows 2013: p. 214)

(Who are those ladies

Who go (many) sorrowing

To the curiosity of their father?

To many men

They have caused harm;

With that they must spend their lives.) (Burrows 2013: p. 215)

This riddle is one of a number of variations on the subject "waves" that present the subjects as destructive females. Other variations depict the waves as ungentle and as having pale hair or white hoods, which would seemingly reflect the foamy white crests of waves. ${ }^{14}$ Hannah Burrows notes that the anthropomorphisation of waves as women was a common trope in Old Norse poetry and comes from Old Norse mythology in which the giants of the ocean, Ægir and Rán (a female creature with a propensity for destroying ships and capturing men), have seven daughters (2013: p. 199). "The riddles' personification of the waves as women," says Burrows, "is thus situated as part of a wider-spread convention, with a rich tapestry of mythological allusion behind it" (2013: p. 199). These wave-women are much like the Valkyrie figures on the battlefield who, as "malevolent, destructive, corrupt" creatures, would bring about the deaths of warriors (Damico 1990: p. 177). The primary aim of invoking these figures on the battlefield or in the sea, says Judy Quinn, was to provide consolation. "The depiction of frolicking waves that lured sailors to join them," Quinn asserts, "or of Ran drawing men down to her beneath the surface of the ocean, allowed poets to transform tragic loss of life into the consolation of powerful elemental forces pulling men irresistibly towards them" (2014: p. 94). Yet behind this consolation lies fear too; these women are beyond the control of a paternal figure and, husbandless, are sjaldan bliðar (seldom gentle) to the men they encounter. Fear of nature and the unknown becomes equated with fear of the powerful, unbridled woman. Like the female waves of the Icelandic riddles, the iceberg of Riddle 33 is beautiful and malevolent, "desirable but dangerous" (Burrows 2013: p. 202), with the ability to destroy men in their ships. Yet Riddle 33's subject is not used as a way to "transform tragic loss of life" into consolation; the focus is on violent destruction and terror.

${ }^{14}$ For all the variations of the "wave" riddle see Burrows (2013: pp. 214-216). 
One further analogue I wish to discuss here is the Anglo-Saxon metrical charms, in particular the charm For a Sudden Stitch. The charms, with their weapon-wielding women who terrify with their loud voices, add a final layer to this discussion of destructive females. The Anglo-Saxon metrical charms were used to defend against evil or cure disease and often required the speaker to perform elaborate rituals whilst speaking them (Cameron 1993: p. 157). In a 2014 article, Sara Frances Burdorff argues convincingly that there are parallels to be found between Grendel's Mother and the women from the charms, but a parallel can also be drawn between these female figures and the female warrior of Riddle 33. One of the most compelling comparisons Burdorff makes between the charm women and Grendel's Mother is the linguistic similarities between the two. She gives the example of gryre which is used to describe the nature of disease in the charms and the terrifying nature of Grendel's Mother (Burdorff 2014: pp. 94, 95). She also discusses the use of wifcompounds in both texts and the depiction of the martial females as mihtig (p. 95). Aside from linguistic similarities, Burdorff also finds imagistic and verbal parallels between the women, including their power and aggressive behaviour, their vaguely female physicality and the nature of their swift appearance and disappearance (pp. 96, 97). Such similarities can be found between the martial women in these texts and the warrior woman of Riddle 33. The riddle's warrior is also vaguely feminine in appearance (being a combination of ice and woman whose physicality is barely described), aggressive towards her "enemies" and, as noted earlier, has a laugh described as gryrelic. The iceberg/warrior woman also occupies a similar liminal space between land and water as the creatures in the charms and Grendel's Mother.

What unites the women of these texts the most is the fear they inspire and the role their gender plays in generating that fear. These women all enter the male arena of war wielding weapons, but they are equipped with other powers associated with their gender that make them even more terrifying. The iceberg/warrior woman is not only able to cause damage physically but also verbally, through the curse she speaks, and this is a power typically associated with her gender. ${ }^{15}$ The spoken word can be talismanic, as the charm Against a Dwarf suggests, ${ }^{16}$ but it can also cause harm. The word heterune in Riddle 33, which means "charm which causes hatred" or "baleful spell" (Cameron et al. 2018), suggests the woman is using her words in a malignant way. Interestingly, she is not the only woman to use hateful words in the Exeter

\footnotetext{
15 Niles notes that "the general assumption was that people with evil tongues were more likely to be female than male" (Niles 2006: p. 179).

16 Having described the entrance of the malevolent creature, the author says:

Pa com in gangan dweores sweostar;

pa geændade heo and aðas swor

ðæt næfre pis ðæm adlegan derian ne moste,

ne pæm pe pis galdor begytan mihte,

oððe pe pis galdor ongalan cupe. (Dobbie 1942: pp. 121-2, 11. 13-17)
}

(Then the beast's sister came walking in. Then [she] stopped and swore this oath: that this disease will never injure them, nor them who might obtain this charm, or they who know how to speak this charm.) 
Book riddle collection; the woman of Riddle 20 does too, and against the riddle's hagostealde (bachelor) subject:

heo me wom spreceð,

floceð hyre folmum, firenap mec wordum, ungod gæleð. Ic ne gyme pæs, compes ... (11. 33b-6)

(she utters injury to me, claps her hands, abuses me with words, chants evil. I do not care for that battle.)

We are previously told that the subject, literally a sword and metaphorically a bachelor warrior, is orlegfromne (strong in battle) (1. 15a) and will often gastberend cwelle compwapnum (kill men with battle-weapons) (1l. 8b-9a); yet a woman saying evil things is a "battle" he turns away from. It is implied that this is a fight he cannot win and so he chooses not to engage in it. Here, we have a riddle in which heroic (male) action is set against the harmful (female) curse; for the woman, words are weapons. ${ }^{17}$ In Riddle 33, we have a woman who is both physically strong and equipped with harmful words. As such, she is a double threat-Craig Williamson's term "witch-warrior" might indeed be the most fitting for her (2011: p. 20).

Notably, the iceberg/warrior woman's curses appear to have a binding quality. We are told that she heterune bond (bound a hateful curse) (1. 7b). The writer here might be playing with the binding qualities of water and ice-the narrator of The Wanderer, for example, describes his journey over the wapema gebind (binding of waves) (Krapp and Dobbie 1936: 1. 24b), whilst the narrator of Beowulf says that when ice melts God onwindeð walrapas (unwinds the flood-ropes) (1. 1610a)—or might be alluding to the way in which Valkyries bind their victims in fetters (Damico 1990: p. 177). The nature not just of the curse but of the female voice, too, is of interest in these analogues, in terms of both its loudness and the way in inspires fear. In both Riddle 33 and the charm For a Sudden Stitch, emphasis is placed on the loudness of the women's voices. This charm begins:

Hlude wæran hy, la, hlude, ða hy ofer pone hlæw ridan, wæran anmode, ða hy ofer land ridan (Dobbie 1942, p. 122, 11. 3-4).

(They were loud, so loud, when they rode over the hill; they were of one mind when they rode over the land.)

In Riddle 33, the iceberg/woman's shout hlinsade hlude (resounded loudly) (1. 3a), similarly placing emphasis on noise. Also of note is the sound of her laughter, which is described as terrible. This sound has echoes, perhaps, of the laughter of the Valkyrie Brynhild at the news of Sigurd's death (see Rafn 1829: p. 209). It is a

\footnotetext{
17 See Niles, who discusses the "widespread anxiety concerning the tendency of women to use words as weapons" (2006: p. 182). Niles also asserts that "the mental world of the [Anglo-Saxons] must have been permeated by the notion that people were capable of doing harm to others through the power of their words" (p. 184).
} 
laugh that pre-empts victory and revels in destruction. It is a laugh that secures this woman's identity as a monstrous source of fear and violence.

\section{II}

Thus far, the focus of this study has been on the female figure of Riddle 33, but in order for this to be a truly ecofeminist approach we need to think about the depiction of the iceberg as an entity in and of itself. That is, we need to explore the representation of the literal iceberg behind the metaphorical woman. Nature is frequently bound up in metaphor in the Exeter Book riddles, as metaphor plays a key role in the riddle genre. An ecocritic's challenge, as Gillian Rudd notes, is to "read with an awareness of allegory, whilst also focusing on the actual animal, plants, rocks or seas under debate" (2007: p. 11). As I have argued in a recent publication, "sometimes it is by considering the anthropocentric metaphors applied in the riddles that important attitudes to the natural world are revealed" (Dale 2017: p. 22). The relationship between the metaphorical female figure and the literal iceberg is an interesting one for ecofeminists. The purpose of a metaphor is to find a "likeness, often a novel or surprising likeness, between two or more things" (Davidson 1979: p. 29). There are certainly some elements of the riddle's two identities that correlate- the loud sound of an iceberg ${ }^{18}$ and the shout of a warrior woman and the destructive potential of both of them-but when the creature is said to speak in riddles about its own ancestry, the riddle refuses "one-to-one correspondence" (Beechy 2010: p. 96). The riddles will often make a distinction between a first-person voice (narrator) and the actual abilities of a subject to speak, ensuring that the boundary of impossibility is not crossed. For example, the ox of Riddle 72 is granted the power to speak through the medium of poetry but the riddle-writer acknowledges that it swigade (is silent) (1 .15b) (see Dale 2017: pp. 68, 69). It could be argued that the curse in Riddle 33 is written rather than spoken, likening the way an iceberg carves up a ship to the engraving of runes (see Beechy 2010: p. 96). However, even if this was the intention, we are still told that the subject speaks about its own creation, which "shifts the guesser's sense of the medium away from writing towards speaking" (Beechy 2010: p. 96). From an ecocritical perspective, the literal voice is problematic, since it diminishes the intrinsic nature of the natural entity that it is seeking to depict (Dale 2017: pp. 68, 69).

Likewise, the mother-daughter concept in the final lines refuses "one-to-one correspondence." Whilst it adequately reflects the melting and freezing of water, it does not reflect the nature of human production; it is impossible for a woman's mother and daughter to be the same person. Consequently, throughout the riddle we are made to focus and defocus our attention on these two identities at different times, according to what is being described. The riddle does not allow for the easy shift from metaphor to literal object that Riddle 5, for example, does, with its depiction of

\footnotetext{
18 The sound of bubbles escaping from an iceberg when it starts to melt has been described as a "deafening roar." See Brown (2012: p. 55).
} 
the shield as a wounded warrior. This requirement is potentially problematic for an ecofeminist looking at the depiction of two marginalised groups: women and nature. When looking purely at the relationship between humans and nature from an ecocritical perspective in the riddles, as opposed to women and nature, it is useful practice to defocus the human metaphor in order to explore the intrinsic characteristics of the natural entity beneath it. When viewing the text from an ecofeminist perspective we have to push one marginalised perspective into the background in order to explore the other. And in Riddle 33 the warrior woman appears to be the more dominant of the two figures, which can make us overlook the natural entity that is the literal subject of the text.

Careful reading of the riddle, however, can find a shared narrative between these two oppressed groups. For example, there is something empowering for both the iceberg and the woman in the speaking of the riddle within the riddle. One of the key themes of the riddle is mystery, not just in terms of the subject's identity but in terms of the iceberg's mysterious origins and the warrior woman's mysterious genealogy. The iceberg is made mysterious because it is the subject of a riddle and therefore goes through a process of mystification, but the origin of icebergs is in itself a mystery. Today we know a lot more about the origin of icebergs than people would have known a 1000 years ago, including their beginnings in the icy north and their journeys out into the Atlantic, and the process of freezing and melting is more scientifically understood. For the Anglo-Saxons these were a source of wonder. Another riddle in the Exeter Book, Riddle 69, depicts the process of freezing as wonderfully mysterious: wundor weard on wege; water weard to bane (a miracle happened on the wave; water turned to bone). ${ }^{19}$ To contemplate the origins of ice or iceberg is to start to appreciate its intrinsic nature; yet it is important to remember that mystery is not part of its intrinsic nature. Icebergs are not by nature mysterious; mystery is an aspect attributed to them by human beings. In the riddle, however, the ultimate mystery, that of its origin, is posed by the iceberg itself. The use of a literal voice may mean that its intrinsic nature is somewhat diminished, but it also means that the mystery of the iceberg is less a state imposed upon it by humans than a state imposed upon it by itself.

The speech act at the end of the riddle also empowers the female subject. The woman defines herself; she is not completely defined by someone else and is able to talk about hyre sylfre gesceaft (her own creation) (1. 8b). She proclaims her peculiar genealogy, speaking of her mother and her daughter (which are one and the same thing). Lees and Overing argue that "the riddle serves to voice not just the mystery of ice...but that of the feminine and of feminine genealogy in particular" (2001: pp. 104). The woman is called searocraftig, which can have both positive and negative connotations depending on context and/or personal interpretation. The term can mean "wily" but it can also mean "skilful" Bosworth and Northcote (1898). Thus, it is possible to see this woman as one skilled in battle and in words; she is defined by her intellect as much as her physical actions and ancestry.

19 This riddle is usually solved as "ice," but Williamson suggests the identity of the subject is, in fact, "iceberg" (1977: p. 335). 
Standing in the way of a truly empowering union between nature and women in Riddle 33 are the andro- and anthropocentric anxieties about the mysterious and fearsome qualities of these two oppressed entities. Yet audiences across time respond differently to texts and modern readers may find something inspiring in the depiction of the warrior woman as an iceberg. Viewed from a new perspective, the figure of Riddle 33 is a woman instilled with the power of the iceberg and the wiggryre of a warrior-not to be defeated or judged, as Grendel's Mother is, against the wiggryre of a man. Together, iceberg and woman have agency and cause harm to those who are behind the bordweallas. Feminine power, not masculine anxiety, is the focus as the female warrior is elevated to the destructive potential of an iceberg. The nature of metaphor-which is to draw two seemingly different things into a comparison-suggests a woman armed with weapons is as formidable as an iceberg (or that an iceberg is as formidable as a woman with weapons). The riddle also reminds us that there are parts of the natural world that cannot be controlled or subjugated under human beings; the iceberg is like the biblical Leviathan in its dominion of the waters and all those who venture into its domain. ${ }^{20}$ The female joins it in this liberated state.

As mentioned previously, feminism has tried to escape the stereotype that joins women and nature and posits women as "potentially fertile females waiting to be plowed and fulfilled" (Cowan 2017: p. 6). One might wonder if Riddle 33 reinforces the nature-women stereotype with its pregnancy/birth metaphor in the final lines, with water as a daughter who has eacen up liden (grown up pregnant) (1.11a). Women, nature, pregnancy: the combination would not seem to move us away from the stereotypical depiction of women and nature. Yet there is something in the quality of the iceberg that offers a new metaphor for women. In the following extract, Lyn Cowan considers the nature-human metaphors waiting to be claimed by women:

Beneath the surface there are coral beds, artesian wells, oil deposits, icebergs, and fossils. All of which may have many meanings attached to them-coral beds of deceptive beauty and natural formations, wells of clean renewal, unlimited wealth of valuable deposits as yet unclaimed by women, icebergs of implacable purpose and hatred when necessary, and fossils - the memory of our foremothers, whose bodies bore us... (2017, p. 6).

Riddle 33 claims the image of a woman as someone of "implacable purpose and hatred," depicting ice and water and its deadly potential, not the reproductive potential of the fertile earth.

To conclude, this study has looked at the possible analogues for Riddle 33, from the "wave" riddles and their Valkyrie-like maidens to the powerful female figures of the metrical charms and Beowulf, and the androcentric anxieties that lie behind them. It is these anxieties that may have led to the depiction of the iceberg/warrior woman as a triple threat: a warrior equipped with both powerful words and skill in battle and an all-female genealogy that is "eternally conceiving." The union of

${ }^{20}$ For a discussion of this concept in the context of the broader riddle tradition, see Dale (2017: pp. 167-194). 
woman and ice in this riddle can be read as symptomatic of the androcentric society in which the text was produced but it can also be seen as a new type of metaphor for women, beyond the essentialist view of women as fertile earth. By "reviewing" the riddle we can find a metaphor that Cowan encourages women to claim: a metaphor not of woman as land, controlled and ploughed, but of woman as strong and implacable as ice.

Open Access This article is distributed under the terms of the Creative Commons Attribution 4.0 International License (http://creativecommons.org/licenses/by/4.0/), which permits unrestricted use, distribution, and reproduction in any medium, provided you give appropriate credit to the original author(s) and the source, provide a link to the Creative Commons license, and indicate if changes were made.

\section{References}

Acker, P. (2006). Horror and the maternal in Beowulf. PMLA, 121(3), 702-716.

Beechy, T. (2010). Bind and loose: Aesthetics and the word in Old English law, charm, and riddle. In J. M. Hill (Ed.), On the aesthetics of Beowulf and other Old English poems (pp. 43-63). Toronto: University of Toronto Press.

Bitterli, D. (2009). Say what I am called: The Old English riddles of the Exeter Book and the Anglo-Latin riddle tradition. Toronto: University of Toronto Press.

Bosworth, J., \& Northcote, T. T. (1898). An Anglo-Saxon Dictionary. Oxford: Clarendon Press.

Brooke, S. A. (1892). The history of early English literature. London: Macmillan.

Brown, R. (2012). Voyage of the iceberg: the story of the iceberg that sank the Titanic. Toronto: James Lorimer.

Burdorff, S. F. (2014). Re-reading Grendel's mother: Beowulf and the Anglo-Saxon metrical charms. Comitatus: A Journal of Medieval and Renaissance Studies, 45, 91-103.

Burrows, H. (2013). Enigma variations: Hervarar saga's wave-riddles and supernatural women in Old Norse poetic tradition. Journal of English and Germanic Philosophy, 112(2), 194-216.

Cameron, M. L. (1993). Anglo-Saxon Medicine. Cambridge Studies in Anglo-Saxon England 7. Cambridge: Cambridge University Press.

Cameron, A., Amos, A. C., Healey, A. diP. et al. (Eds.). (2018). Dictionary of Old English: A to I online. Toronto: Dictionary of Old English Project, http://tapor.library.utoronto.ca/doe. Accessed September 5, 2018.

Cowan, L. (2017). Women and land: Reflections on physicality. In L. Gardner \& F. Gray (Eds.), Feminist views from somewhere: Post-Jungian themes in feminist theory (pp. 3-8). London: Routledge.

Dale, C. (2017). The natural world in the Exeter Book riddles. Woodbridge: D. S. Brewer.

Damico, H. (1990). The valkyrie reflex in Old English literature. In H. Damico \& A. Henessey Olsen (Eds.), New readings on women in Old English literature (pp. 176-192). Indianapolis: Indiana University Press.

Davidson, D. (1979). What metaphors mean. In S. Sacks (Ed.), On metaphor. Chicago: University of Chicago Press.

Dobbie, E. V. K. (Ed.). (1942). The Anglo-Saxon minor poems. Anglo-Saxon Poetic Records 6. New York: Columbia University Press.

Estes, H. (2015). Beowulf and the sea: An ecofeminist reading. In B. Schipper, S. Klein, \& S. LewisSimpson (Eds.), The maritime world of the Anglo-Saxons (pp. 209-216). Tempe: Arizona Center for Medieval and Renaissance Studies.

Horner, S. (2001). The discourse of enclosure: Representing women in Old English literature. New York: SUNY Press.

Klaeber, F. (Ed.). (1922). Beowulf and the fight at finnsburg. New York: D C. Heath \& co.

Krapp, G. P., \& Dobbie, E. V. K. (1936). The Exeter Book. Anglo-Saxon Poetic Records 3. New York: Columbia University Press. 
Lees, C. A., \& Overing, G. R. (2001). Double agents: Women and clerical culture in Anglo-Saxon England. Philadelphia: University of Pennsylvania Press.

Lees, C. A., \& Overing, G. R. (2017). Women and water: Icelandic tales and Anglo-Saxon moorings. GeoHumanities, 4, 97-111.

Lucas, A. (1969). The narrator of the Wife's Lament reconsidered. Neuphilologische Mitteilungen, 70, 282-297.

Morgan, G. (2006). Mothers, monsters, maturation: female evil in Beowulf. Journal of the Fantastic in the Arts, 4, 54-68.

Murphy, P. J. (2011). Unriddling the Exeter riddles. University Park: Pennsylvania University Press.

Murphy, P. D. (2018). Introduction. In D. A. Vakoch \& S. Mickey (Eds.), Literature and ecofeminism: Intersectional and international voices (pp. 1-12). Routledge: London.

Murphy, P. D., \& Gaard, G. C. (2000). Introduction. In G. C. Gaard \& P. D. Murphy (Eds.), Ecofeminist literary criticism: Theory, interpretation, pedagogy (pp. 1-14). Urbana: University of Illinois Press.

Niles, J. D. (2006). Old English enigmatic poems and the play of the texts. Studies in the Early Middle Ages 13. Turnhout: Brepols.

Oswald, D. (2010). Monsters, gender and sexuality in medieval English literature. Woodbridge: D. S. Brewer.

Overing, G. R. (2000). The women of Beowulf: A context for interpretation. In P. S. Baker (Ed.), The Beowulf reader (pp. 219-260). London: Routledge.

Plumwood, V. (2002). Environmental culture: The ecological crisis of reason. London: Routledge.

Potkay, M. B., \& Evitt, R. M. (1997). Minding the body: Women and literature in the Middle Ages, 8001500. London: Twayne Publishers.

Quinn, J. (2014). Mythologizing the sea: The Nordic Sea Deity Rán. In T. R. Tangherlinip (Ed.), Nordic mythologies: Interpretations, intersections, and institutions (pp. 71-99). Berkeley: North Pinehurst Press.

Rafn, C. C. (Ed.). (1829). Fornaldar sögur nordrlanda (Vol. 1). Kaupmannahofn: Enni Popsku.

Reidinger, A. R. (2004). The formulaic style in the Old English riddles. Studia Neophilologia, 76, 30-43.

Rudd, G. (2007). Greenery: Ecocritical readings of late medieval literature. Manchester: Manchester University Press.

Trilling, R. (2007). Beyond abjection: The problem with Grendel's mother again. Parergon, 24, 1-20.

Tupper, F. (Ed.). (1910). The riddles of the Exeter Book. Boston: Ginn.

Williamson, C. (Ed.). (1977). The Old English riddles of the Exeter Book. Chapel Hill: University of North Carolina Press.

Williamson, C. (Ed.). (2011). A feast of creatures: Anglo-Saxon riddle songs. Philadelphia: University of Pennsylvania Press. 